\title{
Hierarchical analysis of determinants of HIV vertical transmission: a case-control study
}

Poliana Germano Bezerra de Sá Siqueira 1

D https://orcid.org/0000-0003-0586-1734

Gabriella Morais Duarte Miranda 2

D https://orcid.org/0000-0001-9588-6817

Wayner Vieira de Souza 3

https://orcid.org/0000-0002-0939-9332

Gerlane Alves Pontes da Silva 4

https://orcid.org/0000-0002-9048-7312
Antonio da Cruz Gouveia Mendes 5

https://orcid.org/0000-0002-3381-134X

1,3,5 Centro de Pesquisas Aggeu Magalhães. Campus da UFPE. Av. Prof. Moraes Rego, s.n. Cidade Universitária. Recife, PE, Brasil. CEP: 50.670-420. E-mail: poligermano@hotmail.com

2 Departamento de Medicina Social. Universidade Federal de Pernambuco. Recife, PE, Brasil

4 Instituto de Medicina Integral Prof. Fernando Figueira. Recife, PE, Brasil.

\begin{abstract}
Objectives: to analyze the association of socioeconomic, obstetric, pediatric and prophylactic factors to the vertical transmission of HIV in children followed at a reference service in Recife between 2010 and 2015.

Methods: case-control nested the cohort of children exposed to vertical transmission of HIV. A univariate and multivariate statistical analysis was performed on the association of socioeconomic, obstetric, pediatric and prophylactic measures with the outcome. We considered two multivariate approaches, conventional and hierarchical, the latter made it possible to consider different levels of determination.

Results: $46.5 \%$ of the mothers had low schooling, $69.6 \%$ without work-related wages and $35.7 \%$ received a family grant. Women with postpartum diagnosis and less than 6 prenatal appointments had a greater chance of vertical transmission. Prophylactic measures were statistically associated with prevention of transmission $(p<0.1 \%)$.

Conclusions: vertical risk factors for HIV transmission were identified: no sewage system, at least six prenatal consultations, first care of the child with more than two months and no prophylaxis in pregnancy and childbirth. Determining factors for which specific policies and programs exist and their non-access social determination evidence of HIV vertical transmission.
\end{abstract}

Key words Vertical transmission of infectious disease, HIV, Risk factors, Multivariate analysis

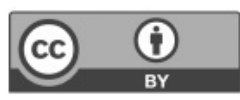




\section{Introduction}

In Brazil, the HIV/AIDS epidemic expansion was concentrated mainly in regions with the worst socioeconomic conditions; in the vertical transmission context, this scenario was also identified.1,2 Brazilian studies 1,3 indicate poverty conditions, low schooling level, and income as structures of vulnerability to HIV infection. This concept was incorporated into the public health from the necessity of intersect in different fields of knowledge to face AIDS strategies. 4

HIV vertical transmission is a multifactorial event, with risk and protective factors, including mainly maternal, obstetrics, pediatrics, and socioeconomics characteristics.1,2,5 The existence of multiple factors involved in its dynamics, among them the social context, leads to inequality and vulnerable exposure. This comprehension on health as a social phenomenon is a product of discussions during decades on health-disease process. 6

The increased incidence of cases of heterosexual transmission contributed to the epidemic expansion among women, becoming a decisive factor in disseminating the virus to children. 3 The HIV vertical transmission (VT) is characterized as a virus infection passed on from mother to child during pregnancy, childbirth, or puerperium, with different chances of transmission at every moment in the pregnancy-puerperal cycle. ${ }^{7}$

In 2016, about 2.1 million children up to the age of 15 lived with HIV worldwide, and the vertical transmission is responsible for more than $90 \%$ of these cases. ${ }^{8}$ In Brazil, in 2018, the vertical transmission was responsible for $86.2 \%$ of HIV/AIDS cases in children under the age of 13.9 In Pernambuco State, this proportion was $93.3 \%$ from 2014 to 2017.10

Since the appearance of the disease and its vertical transmission identification, prophylactic measures reduce the probability of mother-to-child transmission. Besides, advances in antiretroviral therapy have made it possible to reduce VT by approximately two thirds, when associated with other prophylactic interventions. ${ }^{11}$ Thereby, this decrease remains a big challenge for the national public health, mainly due to social inequalities in Brazil, which impair the implementation of control measures.

Thus, this present study aimed to analyze the association of factors on socioeconomic and demographic, obstetrics, pediatrics, and prophylactic measures to HIV vertical transmission in children assisted at a reference service in Recife, Pernambuco
State, Brazil, from 2010 to 2015.

\section{Methods}

An observational study, case-control type, based on a children's cohort exposed to HIV vertical transmission, was performed at the Serviço Atenção Especializada Pediátrico (SAE) (Pediatric Specialized Care Service) at the Instituto de Medicina Integral Professor Fernando Figueira (IMIP), a reference center in the Northeast for this population.

The criteria for HIV vertical transmission diagnosis (VT) proposed by the Clinical Protocol and therapeutic guidelines from the Ministry of Health ${ }^{11}$ were used for HIV infection management in children and adolescents.

A bilateral significance level of $5 \%$ and $80 \%$ power was adopted for the sample. Four controls were included for each case (4:1), considering a hypothetical proportion on the control with $10.0 \%$ exposure and minimum odds ratio (OR) to detect 2.5. The sample counted 415 individuals, with 83 cases and 332 controls.

In case and controls selection, a computerized database from SAE was accessed with the information of children born from 2010 and 2015 exposed to HIV vertical transmission followed up in the service. Those without a definitive diagnosis or who did not have an appointments until they were discharged from the service were excluded. A systematic sampling of children exposed to HIV vertical transmission and uninfected to select the controls was performed, and the case group was composed of all the infected.

The dependent variable was HIV vertical infection in the child and the independent variables were organized in socioeconomic and demographic characteristics (age, schooling, mother's occupation, illicit drug use, newborn race/color, homeownership, participation in the Bolsa Familia Program, water supply, and sanitation), obstetrics and pediatrics (mother diagnosis moment, prenatal care, type of childbirth, rupture of amniotic membranes - before or during labor, newborn gestational age, birth weight and the newborn /child's age at the first appointment in SAE) and prophylactic measures (prophylaxis during pregnancy, prophylaxis at childbirth, newborn prophylaxis and breastfeeding suspension).

The obtained data from the initial evaluation sheets and medical records were organized in worksheets, using Excel for Windows. The IBM SPSS program, version 19, was used to perform a 
univariate statistical analysis of the association of socioeconomic and demographic, obstetrics, pediatrics, and prophylactic measures characteristics with an outcome of each group. The odds ratio (OR) and the $95 \%$ bilateral confidence interval (CI) were calculated to measure the connection between the risk factors and HIV vertical transmission.

In the multivariate analysis, two approaches were considered, one conventional and one hierarchical; this latter enables to approach different levels of determination seeking to reduce distortions of the distal effects. ${ }^{12}$ In the first logistic regression model, all the independent variables statistically associated in the univariate analysis were included $(p \leq 0.20)$. The variables that presented $p \leq 0.10$ were kept in the final model.

In the multivariate hierarchical regression, the independent variables were organized in determination levels, on distal level (maternal schooling, mother's occupation, drug use, newborn race/color, participation in the Bolsa Família Program, water supply, sanitation, and homeownership), intermediate (number of prenatal appointments, gestational age at childbirth, type of birth, rupture of amniotic membranes, mother's age, birth weight, first appointment age) and proximal (maternal diagnosis moment, prophylaxis during pregnancy, birth prophylaxis, newborn prophylaxis, breastfeeding suspension).

The procedures proposed by Victora et al. 12 to perform the hierarchical logistic regression were followed. The variables statistically associated with the univariate analysis outcome are included in the multivariate models corresponding to their determination level. The variables related to the outcome were kept in the final model of each hierarchical level with a value of $p \leq 0.10$. When performing the hierarchical logistic regression, the distal variables are incorporated into the model, preserving themselves as adjustment factors for the hierarchically inferior variables, along with the intermediate variables, creating a new model. Only the intermediate level variables with $p>0.10$ are removed. After that, all the proximal level statistically significant variables are included in this new model, remaining in the final model all the previously identified variables and those of the proximal group that remained in this last stage.

This study was submitted and approved by the Human Research Ethics Committees from the Instituto Aggeu Magalhães (IAM) and the Instituto de Medicina Integral Professor Fernando Figueira with the registration of CAAE document: 55266116.6 .0000 .5190 .

\section{Results}

In Table 1, it is possible to verify the socioeconomic and demographic variables from the control and case groups. $16.1 \%$ were teenage mothers and $46.5 \%$ women with low schooling. Approximately $70 \%$ of the mothers do not receive wages from work, and $35.7 \%$ reported to receive money from the Bolsa Familia Program. As for housing, $60.2 \%$ of the women lived in their own homes, and over $70 \%$ of the households had water supply by the distribution of the public network and sanitary sewerage. The following statistical variables presented the importance in the analysis: homeownership, water supply by the distribution of the public network, and sewerage.

Regarding to the obstetrics and pediatrics characteristics (Table 2), it has been shown that $73.0 \%$ of the maternal diagnoses were before childbirth. The chances of being infection by HIV vertically was 4.2 $(\mathrm{CI} 95 \%=2.24-8.06)$ times higher in children where the maternal diagnosis occurred during childbirth and $25.3(\mathrm{CI} 95 \%=10.80-59.15)$ times greater in those where the diagnosis occurred only in the postpartum.

Concerning prenatal care, approximately $1 / 3$ of the pregnant women did not perform the minimum of six appointments. The chances of HIV infection vertically was $3.5(\mathrm{CI} 95 \%=1.95-6.35)$ times higher than those with complete prenatal care.

It was found that $66.0 \%$ of the childbirths were cesarean sections. In this study, vaginal delivery presented a chance of virus transmission of 3.0 $(\mathrm{CI} 95 \%=1.79-4.89)$ times greater than cesarean sections. As for the amniotic membrane's rupture, $63.1 \%$ of the childbirths occurred with the amniotic sac intact.

It was observed that about $2 / 3$ of the children received specialized care in the first two months of life. The chance of vertical transmission was 3.2 $($ CI95\% $=1.61-6.33)$ times higher among children on their first specialized care by the age of two in less than six months, reaching 31.5 (CI95\%=15.10$65.73)$ times higher in the category of children six months or older.

According to Table 3, all prophylactic measures were statistically associated with HIV vertical transmission prevention $(p<0.01 \%)$. The chemoprophylaxis was performed in $65.3 \%$ of the mothers during pregnancy, $67.7 \%$ at childbirth, and $86.3 \%$ of newborns. Approximately $2 / 3$ of the newborns did not breastfed.

The chances of HIV vertical transmission was ten or more times higher in the group, which did not 


\section{Table 1}

Univariate analysis on the socioeconomic and demographic characteristics associated with mother-to-child HIV transmission. Specialized Care Service, 2010-2015.

\begin{tabular}{|c|c|c|c|c|c|c|c|c|c|}
\hline \multirow[t]{2}{*}{ Variables } & \multicolumn{2}{|c|}{ Case $(\mathrm{N}=83)$} & \multicolumn{2}{|c|}{ Control $(\mathrm{N}=332)$} & \multicolumn{2}{|c|}{ Total $(\mathrm{N}=415)$} & \multirow[t]{2}{*}{ OR } & \multirow[t]{2}{*}{$\mathrm{Cl} 95 \%$} & \multirow[t]{2}{*}{$p$} \\
\hline & $\mathrm{n}$ & $\%$ & $\mathrm{n}$ & $\%$ & $\mathrm{n}$ & $\%$ & & & \\
\hline \multicolumn{10}{|c|}{ Maternal age (years) } \\
\hline$<20$ & 14 & 17.9 & 53 & 16.1 & 67 & 16.1 & 1.14 & $0.60-2.19$ & 0.686 \\
\hline$\geq 20$ & 64 & 82.1 & 277 & 83.9 & 341 & 82.2 & 1 & & \\
\hline Unknown & 5 & & 2 & & 7 & 1.7 & & & \\
\hline \multicolumn{10}{|c|}{ Mother's schooling level (years) } \\
\hline$<8$ & 39 & 51.3 & 154 & 47.2 & 193 & 46.5 & 1.18 & $0.71-1.94$ & 0.522 \\
\hline$\geq 8$ & 37 & 48.7 & 172 & 52.8 & 209 & 50.4 & 1 & & \\
\hline Unknown & 7 & & 6 & & 13 & 3.1 & & & \\
\hline \multicolumn{10}{|c|}{ Mother's occupation } \\
\hline Unpaid & 56 & 75.7 & 233 & 72.4 & 289 & 69.6 & 1.19 & $0.66-2.13$ & 0.563 \\
\hline Paid & 18 & 24.3 & 89 & 27.6 & 107 & 25.8 & 1 & & \\
\hline Unknown & 9 & & 10 & & 19 & 4.6 & & & \\
\hline \multicolumn{10}{|l|}{ Illicit drugs use } \\
\hline Yes & 6 & 10.0 & 28 & 12.2 & 34 & 8.2 & 0.80 & $0.32-2.04$ & 0.642 \\
\hline No & 54 & 90.0 & 202 & 87.8 & 256 & 61.7 & 1 & & \\
\hline Unknown & 23 & & 102 & & 125 & 30.1 & & & \\
\hline \multicolumn{10}{|c|}{ Newborn race/color } \\
\hline White & 3 & 5.3 & 7 & 3.8 & 10 & 2.4 & 1 & & \\
\hline Mixed/Black & 54 & 94.7 & 179 & 96.2 & 233 & 56.1 & 0.7 & $0.18-2.82$ & 0.620 \\
\hline Unknown & 26 & & 146 & & 172 & 41.4 & & & \\
\hline \multicolumn{10}{|c|}{ Bolsa Família Program } \\
\hline Yes & 29 & 48.3 & 119 & 42.5 & 148 & 35.7 & 1.27 & $0.72-2.21$ & 0.409 \\
\hline No & 31 & 51.7 & 161 & 57.5 & 192 & 46.3 & 1 & & \\
\hline Unknown & 23 & & 52 & & 75 & 18.1 & & & \\
\hline \multicolumn{10}{|c|}{ Houseownership } \\
\hline Yes & 51 & 72.9 & 199 & 64.8 & 250 & 60.2 & 1 & & \\
\hline No & 19 & 27.1 & 108 & 35.2 & 127 & 30.6 & 0.69 & $0.39-1.22$ & 0.201 \\
\hline Unknown & 13 & & 25 & & 38 & 9.2 & & & \\
\hline \multicolumn{10}{|l|}{ Water supply } \\
\hline Yes & 56 & 82.3 & 266 & 88.4 & 322 & 77.6 & 1 & & \\
\hline No & 12 & 17.7 & 35 & 11.6 & 47 & 11.3 & 1.63 & $0.80-3.33$ & 0.182 \\
\hline Unknown & 15 & & 31 & & 46 & 11.1 & & & \\
\hline \multicolumn{10}{|c|}{ Sanitary conditions } \\
\hline Yes & 51 & 76.1 & 252 & 84.3 & 303 & 73.0 & 1 & & \\
\hline No & 16 & 23.9 & 47 & 15.7 & 63 & 15.2 & 1.69 & $0.89-3.20$ & 0.112 \\
\hline Unknown & 16 & & 33 & & 49 & 11.8 & & & \\
\hline
\end{tabular}


Univariate analysis of obstetric and pediatric characteristics associated with mother-to-child HIV transmission. Specialized Care Service, 2010-2015.

\begin{tabular}{|c|c|c|c|c|c|c|c|c|c|}
\hline \multirow[t]{2}{*}{ Variables } & \multicolumn{2}{|c|}{ Case $(\mathrm{N}=83)$} & \multicolumn{2}{|c|}{ Control $(\mathrm{N}=332)$} & \multicolumn{2}{|c|}{ Total $(\mathrm{N}=415)$} & \multirow[t]{2}{*}{ OR } & \multirow[t]{2}{*}{$\mathrm{Cl} 95 \%$} & \multirow[t]{2}{*}{$p$} \\
\hline & $\mathrm{n}$ & $\%$ & $\mathrm{n}$ & $\%$ & $\mathrm{n}$ & $\%$ & & & \\
\hline \multicolumn{10}{|l|}{ Maternal diagnosis } \\
\hline Before childbirth & 30 & 39.5 & 273 & 83.5 & 303 & 73.0 & 1 & & \\
\hline At childbirth & 21 & 27.6 & 45 & 13.8 & 66 & 15.9 & 4.25 & $2.24-8.06$ & $<0.001$ \\
\hline After childbirth & 25 & 32.9 & 9 & 2.7 & 34 & 8.2 & 25.29 & $10.80-59.15$ & $<0.001$ \\
\hline Unknown & 7 & & 5 & & 12 & 2.9 & & & \\
\hline \multicolumn{10}{|l|}{ Prenatal care } \\
\hline$<6$ visits & 36 & 63.2 & 97 & 32.8 & 133 & 32.0 & 3.52 & $1.95-6.35$ & $<0.001$ \\
\hline$\geq 6$ visits & 21 & 36.8 & 199 & 67.2 & 220 & 53.0 & 1 & & \\
\hline Unknown & 26 & & 36 & & 62 & 14.9 & & & \\
\hline \multicolumn{10}{|l|}{ Type of delivery } \\
\hline Vaginal & 42 & 53.2 & 91 & 27.7 & 133 & 32.0 & 2.96 & $1.79-4.89$ & $<0.001$ \\
\hline Cesarean & 37 & 46.8 & 237 & 72.3 & 274 & 66.0 & 1 & & \\
\hline Unknown & 4 & & 4 & & 8 & 1.9 & & & \\
\hline \multicolumn{10}{|c|}{ Rupture of amniotic membranes } \\
\hline No & 40 & 67.8 & 222 & 76.8 & 262 & 63.1 & 1 & & \\
\hline Yes & 19 & 32.2 & 67 & 23.2 & 86 & 20.7 & 1.57 & $0.86-2.90$ & 0.145 \\
\hline Unknown & 24 & & 43 & & 67 & 16.1 & & & \\
\hline \multicolumn{10}{|l|}{ Gestational age } \\
\hline Preterm & 8 & 18.6 & 44 & 18.1 & 52 & 12.5 & 1.03 & $0.45-2.38$ & 0.938 \\
\hline Term & 35 & 81.4 & 199 & 81.9 & 234 & 56.4 & 1 & & \\
\hline Unknown & 40 & & 89 & & 129 & 31.1 & & & \\
\hline \multicolumn{10}{|l|}{ Birth weight (g) } \\
\hline$<2.500$ & 16 & 21.6 & 57 & 17.4 & 73 & 17.6 & 1.31 & $0.70-2.44$ & 0.400 \\
\hline$\geq 2.500$ & 58 & 78.4 & 270 & 82.6 & 328 & 79.0 & 1 & & \\
\hline Unknown & 9 & & 5 & & 14 & 3.4 & & & \\
\hline \multicolumn{10}{|c|}{ Age at first medical consultation } \\
\hline$<2$ months & 24 & 28.9 & 252 & 78.3 & 276 & 66.5 & 1 & & \\
\hline 2 months $1-6$ months & 17 & 20.5 & 56 & 17.4 & 73 & 17.6 & 3.19 & $1.61-6.33$ & 0.001 \\
\hline$\geq 6$ months & 42 & 50.6 & 14 & 4.3 & 56 & 13.5 & 31.50 & $15.10-65.73$ & $<0.001$ \\
\hline Unknown & - & & 10 & & 10 & $2 ., 4$ & & & \\
\hline
\end{tabular}

take the chemoprophylaxis in the three moments. The children who received breastmilk had a 16.8 $($ CI95\% $=7.4-7.9)$ times higher of being infected.

Table 4 presents the multivariate regression analysis result, in which four variables were kept in the final model: number of prenatal consultations $(p=0.004)$, child's age at the first appointment $(p=0.044)$, prophylaxis during pregnancy $(p<0.01 \%)$, and at childbirth $(p=0.027)$.

The chances of HIV vertical transmission was greater in children than in mothers who had less than six prenatal consultations $(\mathrm{OR}=4.0 ; \mathrm{CI} 95 \%=1.54$ $10.42)$, in those who had specialized service after two months of age $(\mathrm{OR}=2.6$; CI95\% $=0.82-8.44)$ and mothers who did not take prophylaxis during preg- nancy $(\mathrm{OR}=6.6$; $\mathrm{CI} 95 \%=2.44-18.08)$ and at childbirth $(\mathrm{OR}=3.2 ; \mathrm{CI} 95 \%=1.15-9.02)$.

Table 5 presents the hierarchical logistic multivariate regression final result (adjusted OR 2). On the distal level were included demographic and socioeconomic variables, which showed significance up to 0.20 in the univariate analysis (gross OR) piped water, sewerage, and homeownership adjusted in the socioeconomic model (adjusted OR 1). On the intermediate level, the variables were added: prenatal appointments, type of childbirth, and child's age at the first consultation. The variables included on the proximal level were: maternal diagnosis moment, prophylaxis in pregnancy and childbirth, prophylaxis for newborn, and maternal breast- 
Table 3

\begin{tabular}{|c|c|c|c|c|c|c|c|c|c|}
\hline \multirow[t]{2}{*}{ Variables } & \multicolumn{2}{|c|}{ Case $(\mathrm{N}=83)$} & \multicolumn{2}{|c|}{ Control $(\mathrm{N}=332)$} & \multicolumn{2}{|c|}{ Total $(\mathrm{N}=415)$} & \multirow[t]{2}{*}{ OR } & \multirow[t]{2}{*}{ Cl95\% } & \multirow[t]{2}{*}{$p$} \\
\hline & $n$ & $\%$ & $\mathrm{n}$ & $\%$ & $\mathrm{n}$ & $\%$ & & & \\
\hline \multicolumn{10}{|c|}{ Prophylatic at pregnancy } \\
\hline Yes & 18 & 25.0 & 253 & 77.6 & 271 & 65.3 & 1 & & \\
\hline No & 54 & 75.0 & 73 & 22.4 & 127 & 30.6 & 10.40 & $5.74-18.82$ & $<0.001$ \\
\hline Unknown & 11 & & 6 & & 17 & 4.1 & & & \\
\hline \multicolumn{10}{|c|}{ Prophylatic at delivery } \\
\hline Yes & 24 & 35.3 & 257 & 85.9 & 281 & 67.7 & 1 & & \\
\hline No & 44 & 64.7 & 42 & 14.1 & 86 & 20.7 & 11.22 & $6.19-20.34$ & $<0.001$ \\
\hline Unknown & 15 & & 33 & & 48 & 11.6 & & & \\
\hline \multicolumn{10}{|c|}{ Newborn prophylaxis } \\
\hline Yes & 46 & 63.0 & 312 & 95.4 & 358 & 86.3 & 1 & & \\
\hline No & 27 & 37.0 & 15 & 4.6 & 42 & 10.1 & 12.21 & $6.05-24.66$ & $<0.001$ \\
\hline Unknown & 10 & & 5 & & 15 & 3.6 & & & \\
\hline \multicolumn{10}{|c|}{ Breastfeeding } \\
\hline Yes & 25 & 32.1 & 9 & 2.7 & 34 & 8.2 & 16.77 & $7.42-37.91$ & $<0,001$ \\
\hline No & 53 & 67.9 & 320 & 97.3 & 373 & 89.9 & 1 & & \\
\hline Unknown & 5 & & 3 & & 8 & 1.9 & & & \\
\hline
\end{tabular}

Table 4

Logistic regression model and factors associated with mother-to-child HIV transmission in exposed children followed up at a referral service. Conventional multivariate analysis. Specialized Care Service, 2010-2015.

\begin{tabular}{|c|c|c|c|c|}
\hline Variables & $\begin{array}{c}\text { OR } \\
\text { crude } \\
\text { OR }[\mathrm{Cl} 95 \%]\end{array}$ & $p$ & $\begin{array}{l}\text { OR } \text { adjusted } \\
\text { OR }[\mathrm{Cl} 95 \%]\end{array}$ & $p$ \\
\hline Houseownership & & 0.201 & & \\
\hline Yes & 1 & & & \\
\hline No & $0.69[0.39-1.22]$ & & & \\
\hline Water supply & & 0.182 & & \\
\hline Yes & 1 & & & \\
\hline No & $1.63[0.80-3.33]$ & & & \\
\hline Sanitary conditions & & 0.112 & & \\
\hline Yes & 1 & & & \\
\hline No & $1.69[0.89-3.20]$ & & & \\
\hline Maternal diagnosis & & $<0.001$ & & \\
\hline Before childbirth & 1 & & & \\
\hline At childbirth & $4.25[2.24-8.06]$ & & & \\
\hline After childbirth & $25.29[10.80-59.15]$ & & & \\
\hline Prenatal care & & $<0.001$ & & 0.004 \\
\hline$<6$ visits & $3.52[1.95-6.35]$ & & $4.00[1.54-10.42]$ & \\
\hline$\geq 6$ visits & 1 & & 1 & \\
\hline Type of delivery & & $<0.001$ & & \\
\hline Vaginal & $2.96[1.79-4.89]$ & & & \\
\hline \multirow[t]{2}{*}{ Cesarean } & 1 & & & \\
\hline & & & & continue \\
\hline
\end{tabular}


Logistic regression model and factors associated with mother-to-child HIV transmission in exposed children followed up at a referral service. Conventional multivariate analysis. Specialized Care Service, 2010-2015.

\begin{tabular}{|c|c|c|c|c|}
\hline Variables & $\begin{array}{c}\text { OR } \\
\text { crude } \\
\text { OR }[\mathrm{Cl} 95 \%]\end{array}$ & $p$ & $\begin{array}{l}\text { OR } \text { adjusted } \\
\text { OR }[\mathrm{Cl} 95 \%]\end{array}$ & $p$ \\
\hline Rupture of amniotic membranes & & 0.145 & & \\
\hline No & 1 & & & \\
\hline Yes & $1.57[0.86-2.90]$ & & & \\
\hline Age at first medical consultation & & 0.001 & & 0.044 \\
\hline$<2$ months & 1 & & 1 & \\
\hline 2 months I- 6 months & $3.19[1.61-6.33]$ & & $2.62[0.82-8.44]$ & \\
\hline$\geq 6$ months & $31.5[15.10-65.73]$ & & $4.23[1.18-15.12]$ & \\
\hline Prophylatic at pregnancy & & $<0.001$ & & 0.000 \\
\hline Yes & 1 & & 1 & \\
\hline No & $10.4[5.74-18.82]$ & & $6.64[2.44-18.08]$ & \\
\hline Prophylatic at delivery & & $<0.001$ & & 0.027 \\
\hline Yes & 1 & & 1 & \\
\hline No & $11.22[6.19-20.34]$ & & $3.21[1.15-9.02]$ & \\
\hline Newborn prophylaxis & & $<0.001$ & & \\
\hline Yes & 1 & & & \\
\hline No & $12,21[6.05-24.66]$ & & & \\
\hline Maternal Breastfeeding & & $<0.001$ & & \\
\hline Yes & $16.77[7.42-37.91]$ & & & \\
\hline No & 1 & & & \\
\hline
\end{tabular}

$\mathrm{OR}=$ odds ratio; $\mathrm{OR}_{\text {crude }}=$ univariate analysis; $\mathrm{OR}_{\text {adjusted }}=$ values adjusted by the other variables internally to the level; $\mathrm{CI} 95 \%=95 \%$ of confidence interval; Model adjustment: -2 Log $L R=127.66$ and $R^{2}$ Nagelkerke $=0.46$.

feeding.

In the final model, five variables were present. The sewerage system was kept on the distal level, even losing statistical relevance, because it is an adjustment factor for hierarchically inferior variables. On the intermediate level, the variables on prenatal consultation and child's age at the first consultation proceeded significantly associated to the outcome after the adjustments of other variables. Finally, on the proximal level, prophylaxis in pregnancy and childbirth were remained.

According to the hierarchical model, in the HIV vertical transmission there are some risk factors to be considered: lack of sewage system in the household $(\mathrm{OR}=2.0$; $\mathrm{CI} 95 \%=0.74-5.52)$, not attended to at least six prenatal consultations $(\mathrm{OR}=4.0$; CI95\% $=1.68-9.44)$, child's first assistance at a specialized service between two and less than six months old $(\mathrm{OR}=1.7 ; \mathrm{CI} 95 \%=0.60-4.94)$ and after six months $(\mathrm{OR}=8.1 ; \mathrm{CI} 95 \%=2.57-25.52)$, did not perform prophylaxis during pregnancy $(\mathrm{OR}=3.7$; $\mathrm{CI} 95 \%=1.52-9.06)$ and childbirth $(\mathrm{OR}=3.9$; $\mathrm{CI} 95 \%=1.57-9.59)$.

\section{Discussion}

The analysis of the results showed an essential proportion of mothers with low schooling, mixed and black-skinned, with no paid occupation and participants of the Bolsa Familia Program. These individual and social factors overlapped the lack of a diagnosis at the right moment and an inadequate number of consultations during prenatal and a late follow-up on children with a positive diagnosis. It suggests that they are the most vulnerable subjects who still need more significant intervention and different strategies.

The results of the study revealed a higher percentage of mothers over 20 years old in both groups; however, it was also seen a significant proportion of pregnant teen women. Thus, studies in the United Kingdom and Ireland 13 and specialized care services in Brazil14-16 indicate that the age group, which concentrates the highest proportion of HIV-positive are 20 to 39 years old adults.

As for maternal schooling, there was an essential difference in the groups. Low schooling and unpaid job and participation in the Bolsa Familia Program 
Table 5

Logistic regression model for factors associated with mother-to-child HIV transmission in exposed children followed up at a referral service. Hierarchical multivariate analysis. Specialized Care Service, 2010-2015.

\begin{tabular}{|c|c|c|c|c|c|c|}
\hline Level & $\begin{array}{c}\text { OR }_{\text {crude }} \\
\text { OR [Cl95\%] }\end{array}$ & $p$ & $\begin{array}{l}\text { OR }_{\text {adjusted1 }} \\
\text { OR [Cl95\%] }\end{array}$ & $p$ & $\begin{array}{l}\text { OR }_{\text {adjusted2 }} \\
\text { OR [Cl95\%] }\end{array}$ & $p$ \\
\hline \multicolumn{7}{|l|}{ Distal level } \\
\hline Sanitary conditions & & 0.112 & & 0.065 & & 0.173 \\
\hline Yes & 1.00 & & 1.00 & & 1.00 & \\
\hline No & $1.68[0.89-3.20]$ & & $1.84[0.96-3.53]$ & & $2.02[0.74-5.52]$ & \\
\hline \multicolumn{7}{|l|}{ Intermediate level } \\
\hline Prenatal care & & $<0.001$ & & 0.001 & & 0.002 \\
\hline$<6$ visits & $3.52[1.95-6.35]$ & & $3.34[1.61-6.92]$ & & $3.98[1.68-9.44]$ & \\
\hline$\geq 6$ visits & 1.00 & & 1.00 & & 1,00 & \\
\hline Age at first medical consultation & & 0.001 & & $<0.001$ & & 0.002 \\
\hline$<2$ months & 1.00 & & 1,00 & & 1.00 & \\
\hline 2 months I- 6 months & $3.19[1.61-6.33]$ & & $2.97[1.17-7.56]$ & & $1.72[0.60-4.94]$ & \\
\hline$\geq 6$ months & $31.50[15.10-65.73]$ & & $9.42[2.67-33.18]$ & & $8.10[2.57-25.52]$ & \\
\hline \multicolumn{7}{|l|}{ Proximal level } \\
\hline Prophylactic at pregnancy & & $<0.001$ & & $<0.001$ & & 0.004 \\
\hline Yes & 1.00 & & 1.00 & & 1.00 & \\
\hline No & $10.40[5.74-18.82]$ & & $5.51[2.70-11.26]$ & & $3.71[1.52-9.06]$ & \\
\hline Prophylatic at delivery & & $<0.001$ & & 0.001 & & 0.003 \\
\hline Yes & 1.00 & & 1.00 & & 1.00 & \\
\hline No & $11.22[6.19-20.34]$ & & $3.57[1.63-7.80]$ & & $3.88[1.57-9.59]$ & \\
\hline
\end{tabular}

$\mathrm{OR}=$ odds ratio; $\mathrm{OR}_{\text {crude }}=$ univariate analysis; $\mathrm{OR}_{\text {adjusted } 1}=$ values adjusted by the other variables internally to the level; $\mathrm{OR}_{\mathrm{adjusted} 2}=\mathrm{values}$ adjusted internally to the level and by the upper level(s); CI95\% = 95\% of confidence interval; Model adjustment: $-2 \mathrm{Log} \mathrm{LR}=153.55$ and $\mathrm{R}^{2}=0.48$.

are socioeconomic indicators of this population and suggest vulnerability increase and HIV transmission risk. In this study, most mothers reported not having a paid job, most of them becoming housewives; despite this, most of them also did not have access to the Bolsa Familia Program. This precarious socioeconomic condition scenario reflects the existing social inequity, impairs access to information, prevention, treatment, and service care, increasing the transmission risk on the lowest population groups. Thus, parents' schooling presents as a child health determinant, since, in general, a higher knowledge level allows a more appropriate care.

The schooling level is linked to acquiring knowledge in health, child health care, and stimulating health services and influencing adherence to antiretroviral therapy. ${ }^{1,17}$ Low schooling has a positive correlation with less knowledge about HIV vertical transmission, and it is characterized as one of the main reasons mothers are not able to take care of their child exposed to HIV. 18

The results showed that the chance of transmit- ting the virus increases the delay in performing maternal diagnosis; this happens mainly because of an appropriate moment for a reduction on the antiretroviral prophylaxis performance. The orientation of HIV prevention on seronegative postpartum women can be highlighted, which can be infected after prenatal and childbirth testing. The diagnosis performed on postpartum increases the chances of HIV transmission due to the viral load of high levels and exposure to contaminated breastmilk.

In the United Kingdom and Ireland, from 2000 to 2011 , a study showed the increase of maternal diagnosis before the pregnancy and the pregnant women's proportion with HIV in TARV treatment; in these countries, most of the population is diagnosed, and $99 \%$ of them carry therapy. ${ }^{19}$ In Brazil, however, detection of infection in pregnant women persist failures, as the challenge of early capture for prenatal care, absence of HIV test request during follow-up, or delay in delivering the test result. These lost opportunities in HIV vertical transmission prevention are reported in the recent medical litera- 
ture. 20,21

The absence of performing prenatal care increased HIV vertical transmission. This way, pregnant women's attendance at medical consultations is essential to prevent virus transmission. During prenatal care, it is possible to diagnose the maternal infection early, antiretroviral therapy implementation as an approach to the maternal infection aiming to reduce viral load and consequently, decrease the child's contamination risk during pregnancy and childbirth, as well as allowing to plan the type of birth and have guidance on the importance of no breastfeeding.

The late HIV detection in pregnant women represents a lost opportunity to prevent the virus from vertical transmission.22,23 Once a longer TARV prenatal duration is associated with a low HIV risk transmission. 19

It was identified that vaginal delivery offered a higher chance of transmitting the virus to the newborn. Although it is not contraindicated, this type of delivery requires some care, such as maternal viral load suppression in the last trimester of pregnancy with antiretroviral therapy use and among others. This result suggests that there were failures in vaginal delivery management care.

A study 24 indicates that cesarean section has a protecting role on HIV vertical transmission; However, it has all the risks associated with surgical intervention, and the transmission can occur even with a low viral load; However, the benefits of an elective cesarean section in women with low viral load due to increased obstetric complications are not elucidated yet.

Regarding postnatal care, it was observed that infected children had late admission to the service. The early access to the service allows a clinical and laboratory follow-up of the HIV exposed child and assistance in chemoprophylaxis. This measure also ensures the professional-user bond, preventing possible follow-up losses and allows an early treatment implementation. It is important to emphasize that the child's age at the first consultation on the specialized service is influenced by factors such as maternal diagnosis moment, prenatal adhesion, family social conditions, and health services.

In medical literature, some problematic aspects to child's follow-up are pointed out, and most problems are on the mothers, such as the mother's lack of knowledge on the follow-up, professionals' failure to guide them and the health services failure to seek them. The parent's low schooling, socioeconomic condition, and non-acceptance of the diagnosis are also reported. Maternal adherence to postnatal follow-up is fundamental in reducing the child's risk of contamination. 25

The factors associated with HIV vertical transmission closely connect with socioeconomic conditions, making the implementation on prevention measures difficult. In Africa, risk factors are related to mixed feeding, home birth, and neonatal prophylaxis abscence 26,27 ; In Brazil, these factors are maternal high virus load and lack of prenatal prophylaxis and vaginal delivery. ${ }^{15,28}$ On the other hand, the United Kingdom and Ireland have a low vertical transmission rate with the continuous reduction due to maternal diagnosis increase and early implementation of antiretroviral therapy, allowing greater access to prophylaxis and increased duration of treatment. 13,19

In this study, hierarchical and conventional multivariate regressions were made, aiming to compare determinants results in HIV vertical transmission. According to the proposed methodology, in the hierarchical analysis presented in the final model, the socioeconomic variable, situated on the distal determination level, remains present after adjusting the variables to other levels, regardless of the significance level. This regression model usage made it possible to highlight the socioeconomic factors in the process of disease determination.

The hierarchical model enabled to identify the factors located in hierarchically higher levels that influenced proximal factors, allowing it to discuss the problem in multiple dimensions. 29 The hierarchical approach represents progress towards conventional regression, enabling the variable organization in determination levels; however, it presents methodological limitations such as the limited representation of interrelationship between hierarchical levels. ${ }^{12}$

Despite the lack of total filling of some sociodemographic and economic variables, such as race/color and drug use, significant to the social context characterization, the completeness percentage on other studied variables helped the consistency of the analyses performed.

In conclusion, at least six minimum prenatal consultations, advanced child's age at the first consultation on specialized service, and the nonprophylaxis performance during pregnancy and childbirth were identified as the most critical risk factors to HIV vertical transmission. Determinant factors for specific policies and existing programs, indicating the necessity for more effective interventions and the social networks strengthening to support HIV-positive mothers and their families. These results highlight social determination, empha- 
sizing the minimal poverty and improving life quality in the society.

\section{Authors' contribution}

All the authors contributed to the design, structuring, analysis and interpretation of the data, and developed or performed the critical review of the article. The final version was approved by all the authors.

\section{References}

1. Lopes EM, Pedrosa NL, Holanda ER, Almeida RLF, Kerr LRFS, Galvão MTG. AIDS em crianças: a influência dos diferenciais socioeconômicos no Município de Fortaleza, Ceará, Brasil. Cad Saúde Pública. 2015;31(9): 2005-16.

2. Stephan C, Henn CA, Donalisio MR. Expressão geográfica da epidemia de Aids em Campinas, São Paulo, de 1980 a 2005. Rev Saúde Pública. 2010;44(5): 812-9.

3. Szwarcwald CL, Barbosa Júnior A, Fonseca MG Estimativa do número de crianças (0-14 anos) infectadas pelo HIV, Brasil, 2000. Bol Epidemiol Aids.2001;25(1):4954.

4. Oviedo RAM, Czeresnia D. O conceito de vulnerabilidade e seu caráter biossocial. Interface. 2015; 19 (53): 237-50.

5. Duarte G, Quintana SM, El Beitune P. Fatores que influenciam a transmissão vertical do vírus da imunodeficiência humana tipo 1. Rev Bras Ginecol Obstet. 2005; 27 (11): 698-705.

6. Maranhão TA, Pereira MLD. Determinação Social do HIV/AIDS: revisão integrativa. Rev Baiana Enferm. 2018; 32: e20636.

7. Brasil. Secretaria de Vigilância em Saúde. Departamento de Vigilância, Prevenção e Controle das Doenças Sexualmente Transmissíveis, Aids e Hepatites Virais. Brasília, DF; 2016.

8. UNAIDS (The Joint United Nations Programme on HIV/AIDS). Fact sheet - Latest global and regional statistics on the status of the AIDS epidemic. Genebra; 2017. 8p.

9. Boletim Epidemiológico DST/AIDS (Brasil). Brasília: Secretaria de Vigilância em Saúde, número especial; 2019.

10. Boletim Epidemiológico DST/AIDS (Pernambuco). Recife: Secretaria Estadual de Saúde, ano 8; 2018.

11. Brasil. Ministério da Saúde. Secretaria de Vigilância em Saúde. Programa Nacional de DST e Aids. Protocolo Clínico e Diretrizes terapêuticas para Manejo da Infecção pelo HIV em Crianças e Adolescentes. Ministério da Saúde, Secretaria de Vigilância em Saúde, Programa Nacional de DST e Aids. Brasília, DF;2014. p.238

12. Victora CG, Huttly SR, Fuchs SC, Olinto MT. The role of conceptual frameworks in epidemiological analysis: a hierarchical approach. Int J Epidemiol.1997;26(1): 224-7.

13. French C, Thorne C, Byrne L, Cortina-Borja M, Tookey P. Presentation for care and antenatal management of HIV in the UK, 2009-2014. HIV Med. 2017; 18 (3): 161-70.

14. Bick MA, Ferreira T, Sampaio CO, Padoin SMM, Paula CC. Perfil de gestantes infectadas e crianças expostas ao
HIV atendidas em serviço especializado do sul do Brasil. Rev Bras Saúde Matern Infant. 2018; 18(4): 791-801.

15. Gouveia PAC, Silva GAP, Albuquerque MFPM. Factors associated with mother-to-child transmission of the human immunodeficiency virus in Pernambuco, Brazil, 20002009. Trop Med Int Health. 2013;18(3): 276-85

16. Rodrigues STC, Vaz MJR, Barros SMO. Vertical transmission of HIV in the population treated at a reference center. Acta Paul Enferm. 2013; 26 (2): 158-64.

17. Gakidou E, Cowling K, Lozano R, Murray CJL. Increased educational attainment and its effect on child mortality in 175 countries between 1970 and 2009: a systematic analysis. Lancet. 2010; 376: 959-74.

18. Jordão BA, Espolador GM, Sabino AMNF, Tavares BB. Conhecimento da gestante sobre o HIV e a transmissão vertical em São José do Rio Preto, São Paulo, Brasil. Rev Bras Pesq Saúde. 2017; 18 (2): 26-34.

19. Townsend CL, Byrne L, Cortina-Borja M, Thorne C, Ruiter A, Lyall H, Taylor GP, Peckham CS, Tookey PA. Earlier initiation of ART and further decline in mother-to-child HIV transmission rates, 2000-2011.AIDS. 2014; 28 (7): 1049-57.

20. Brandão MN, Souza ES, Brito RJV, Cavalcanti MMSG, Brandão MFR, Cavalcante MC. Challenges in preventing vertical HIV transmission in Petrolina, Pernambuco and Juazeiro, Bahia. Rev Bras Saúde Matern Infant. 2016; 16 (3): $313-24$

21. Miranda AE, Pereira GFM, Araujo MAL, Silveira MFT, Tavares LDL, Silva LCF, Moreira-Silva SF, Saraceni V. Avaliação da cascata de cuidado na prevenção da transmissão vertical do HIV no Brasil. Cad. Saúde Pública. 2016; 32 (9): e00118215.

22. Rosa MC, Lobato RC, Gonçalves CV, Silva NMO, Barral MFM, Martinez AMB, Hora VP. Avaliação dos fatores associados à transmissão vertical de HIV-1. J Pediatr. 2015; 91 (6): 523-8.

23. Lenzi L, Souza VR, Wiens A, Maciel KF, Neto JR, Pontarolo R. Adesão à terapia antirretroviral durante a gestação e sua relação com a efetividade na prevenção da transmissão vertical do HIV. Acta Biomed Bras.2015; 4 (2): $12-20$

24. Kakehasi FM, Ferreira FGF, Pinto JA, Carneiro SA. Vírus da imunodeficiência humana adquirida/HIV no período neonatal. Rev Med Minas Gerais. 2014; 24 (2): 241-7. 
25. Torres RC, Ferreira LC, Santos TC, Santos AP, Patrícia V, Oliveira G. Adesão da genitora vivendo com HIV/AIDS no acompanhamento na sororreversão do filho. J Health Connections. 2017; 1 (1): 19-32.

26. Endalamaw A, Demsie A, Eshetie S, Habtewold TD. A systematic review and meta-analysis of vertical transmission route of HIV in Ethiopia. BMC Infect Dis. 2018; 18 (1): 283.

27. Koye DN, Zeleke BM. Mother-to-child transmission of HIV and its predictors among HIV-exposed infants at a PMTCT clinic in northwest Ethiopia.BMC Public Health. 2013; 13 (1): 398.
28. Prado TN, Brickley DB, Hills NK, Zandonade E, MoreiraSilva SF, Miranda AE.Factors associated with maternalchild transmission of HIV-1 in southeastern Brazil: a retrospective study. AIDS Behav. 2018; 22 (Suppl.1): 92-8.

29. Melo MMDC, Souza WV, Couto GBL. Comparação de métodos de regressão multivariada no estudo de determinantes da cárie dentária em crianças. Rev Bras Saúde Matern Infant. 2014; 14 (4): 343-52.

Received on July 3, 2019

Final version presented on July 1, 2020

Approved on September 30, 2020 